\title{
Cultural Heritage and Identity in the Literature of Australian South Sea Islanders and Other Media
}

\author{
Carine Davias
}

\author{
PhD session \\ Paul Valéry University in Montpellier, France
}

\begin{abstract}
Australian South Sea Islanders represent a small community whose ancestors mainly came from Melanesian Islands to work as indentured labour in the sugar cane plantations of Queensland from the 1860 's to the beginning of the $20^{\text {th }}$ century. Many still live near the old sugar towns, but apart from an official recognition of their existence and distinctiveness by the Federal Government in 1994 and by the Queensland Government in 2000, South Sea Islanders' culture, economic and political roles are still underrepresented or even ignored in Australia. In the 1970's, writers belonging to that community, such as Faith Bandler, Mabel Edmund and Noel Fatnowna started to tell their own family history since the arrival of their first ancestors on the continent. These autobiographical accounts enabled them to reassert their identity as a culturally distinct group and to shed light on a part of Australia's forgotten past. Other written testimonies followed at the beginning of the $21^{\text {st }}$ century but the lack of young South Sea Islander writers induced us to look at their other means of expression to promote their culture and complete the missing parts of their personal and collective history.
\end{abstract}

$\mathrm{N}^{\circ}$ owadays in Australia, some 20,000 people identify themselves as Australian South Sea Islanders because at least one of their ancestors had come from a Melanesian or a Polynesian island situated in the South Pacific area to work and settle in the country. Despite their contribution to the development of Queensland's economy and two successful attempts by the national and local governments to recognise their uniqueness in Australia's multicultural society, a large majority of the population here and elsewhere is still unaware of who South Sea Islanders are, what their history is and how they managed to survive in that country. Even less information is available on their writings, which started to be published in the 1970's and on their other means of cultural expression, including documentaries, exhibitions or websites like Facebook and YouTube. All those media enable the South Sea Islander community at large to express their own vision of history as well as preserve and share their cultural heritage and identity, ${ }^{1}$ as this paper $^{2}$ intends to show it. So our first aim

\footnotetext{
${ }^{1}$ This has been my research topic since my arrival in New Caledonia in July 2010. One year later, I registered at Paul Valéry University (PVU) in Montpellier, France, as a PhD student in Literary Studies and Anthropology. A cotutelle program is still under way between PVU and JCU, jointly supervised by Rosita Henry, Victoria Kuttainen, Barbara Glowczewski (Adjunct Professor) and Claire Omhovère.

${ }^{2}$ It was presented at the PhD session on Saturday, 13 ${ }^{\text {th }}$ August 2011.
} 
will be to discuss the general context of their arrival in Australia, then we will focus on their gradual involvement in politics and on the literary scene. Eventually, we will see how the use of more recent media enables South Sea Islanders to interact more freely between communities and with a wider audience.

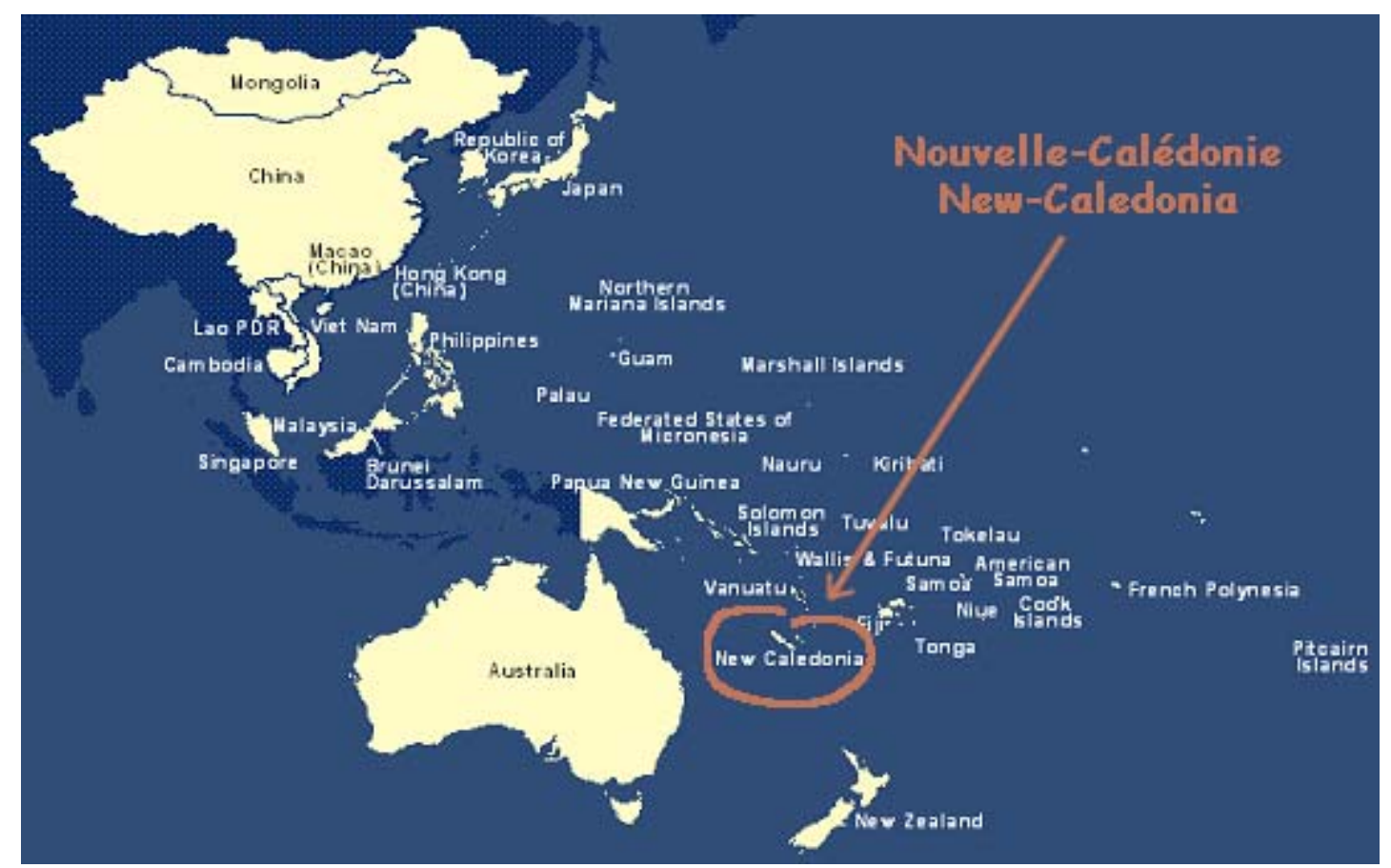

Map of Pacific Islands showing New Caledonia

In her online magazine entitled Storian Blong Yumi, Sonia Minniecon and her team from the Blackbird Association ${ }^{3}$ remind us that early contacts between Pacific Islanders already existed in the middle of the $19^{\text {th }}$ century, especially with the Torres Strait Islands where bêche de mer and pearl shell became valuable commodities. Adventurous Melanesian Islanders often came there to work as divers or seamen on board trading vessels and represented a muchappreciated workforce for their physical strength and knowledge of the sea. As for the first Islanders who arrived on the mainland, they were recruited in the neighbouring islands to work as indentured labour in the cotton and sugar cane plantations of Queensland. In 1863, Robert Towns, a wealthy merchant and ship-owner who later gave his name to Townsville, was one of the first to organize their recruitment and employ them (Docker 10) in order to help develop the sugar industry. ${ }^{4}$ Most workers came from big Melanesian islands like the Solomons, the New Hebrides (Vanuatu) or Papua New Guinea where much workforce was available. Others were recruited in the Loyalty Islands, ${ }^{5}$ the Gilbert Islands (Kiribati) or the

Many thanks to Barbara Glowczewski and Anita Lundberg who invited me to take part in this colloquium and to the JCU libraries'staff in Townsville and Cairns, especially Nathan Miller, who kindly helped me in my research.

\footnotetext{
${ }^{3}$ This association aims at reconnecting families in Australia and the South Pacific, sponsoring students from Vanuatu and raising funds for its reconnection program.

${ }^{4}$ Robert Towns had already started to use them on his ships and in the sandalwood trade, as explained in Ils étaient venus chercher du santal (Shineberg 338-39) and he was satisfied with their work.

${ }^{5}$ Lifou and Maré essentially, Ouvéa and Tiga to a lesser extent as they are tiny islands.
} 
Ellice Islands (Tuvalu) in Polynesia. They were often taken by force, trickery or persuasion mainly to work in Queensland but also in other colonies like Fiji, Western Samoa, New Caledonia or even Peru. That labour trade between South Pacific islands and European colonies quickly became known as "blackbirding" when it implied the abduction of black labourers. J.M.G.Le Clézio, the winner of the 2008 Nobel Prize for Literature, dedicates one chapter to this phenomenon in his Raga ${ }^{6}$ novel which is set on Pentecost Island in Vanuatu. He compares the labour trade to a new form of slavery ${ }^{7}$ that does not speak his name (48).

From 1863 to 1904, it is considered that about 62,000 Pacific Islanders were recruited to work as indentured labour in Queensland. White planters and traders pejoratively called them "Kanakas" as a synonym for "boys" (Delathière 8) although the original meaning of this Hawaiian term is "human being" or "person" (Koppel 1). It was used in the first place by Hawaiians to name those among them who had chosen to set sail for British Columbia in Canada or for the Pacific Northwest at the end of the $18^{\text {th }}$ century, after James Cook discovered Hawai'i in 1788 on his third and last expedition in search of the Northwest Passage. ${ }^{8}$

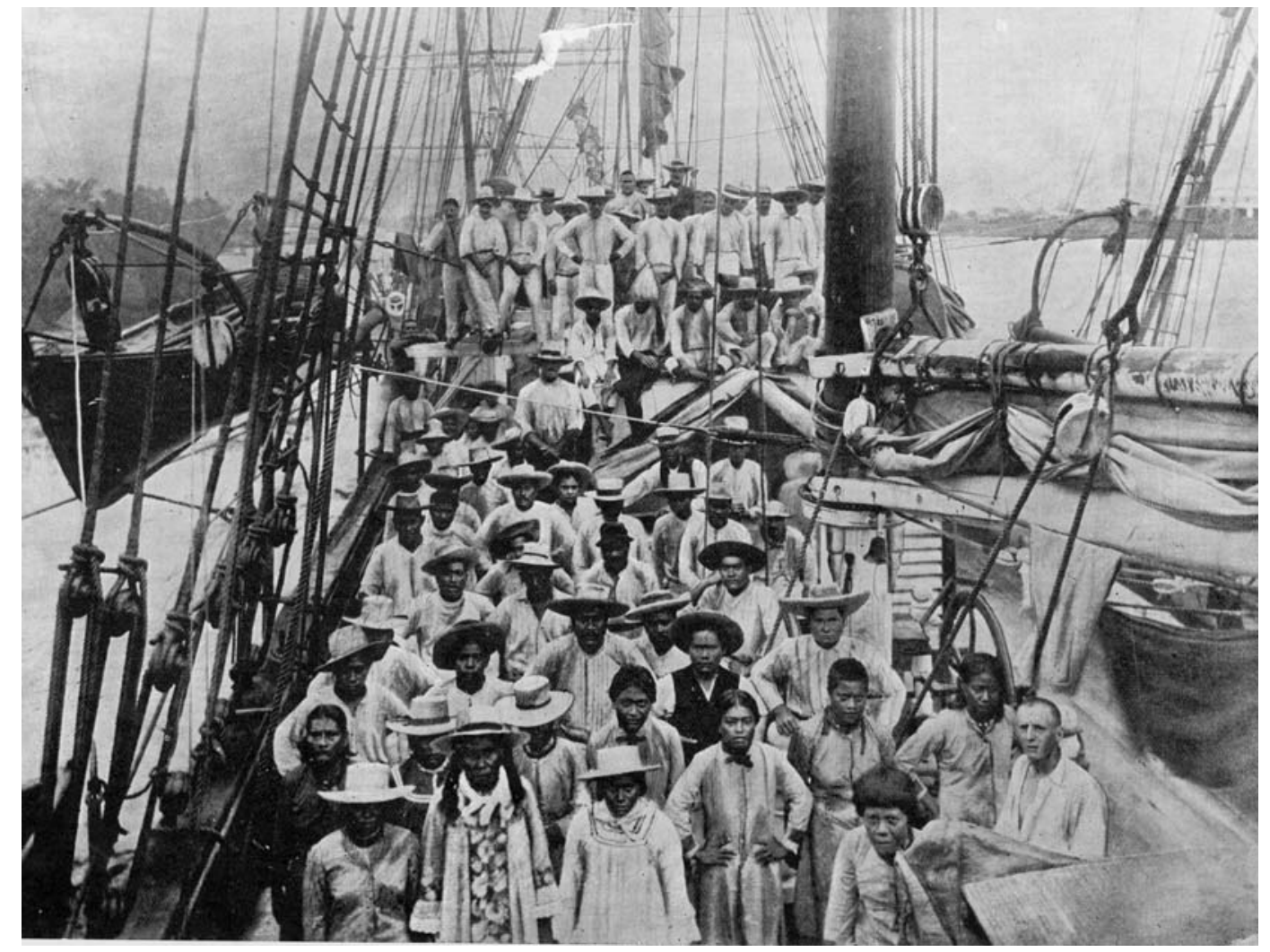

South Sea Islanders on the deck of a ship arriving at Bundaberg in 1895. John Oxley Library, State Library of Queensland. Neg: 16954

\footnotetext{
${ }^{6}$ According to the online Encyclopedia Britannica, Raga is the former name of Pentecost Island.

${ }^{7}$ Britain abolished slavery in 1830 and France in 1848.

${ }^{8}$ Hawai'i is the place where he was killed by Indigenous people on 14th February 1779 during a fight over the theft of a cutter.
} 
Some became crew members to supply shortages on trading ships but most were employed as servants in the fur trade for the Hudson's Bay Company (Koppel 8). Like the Islanders recruited in the South Seas, those Polynesians represented a cheap, docile labour force who toiled in menial jobs from dawn to dusk. As time went on, the derogatory term "Kanaka" came to encompass all the indigenous people from Oceania (Bensa 55) before exclusively referring to those from New Caledonia in 1970, when the Kanak ${ }^{9}$ people proudly chose that name to illustrate their fight for the recognition of their identity and the independence of their country: Kanaky. A good look at New Caledonia's history reveals that the former French penal colony also resorted to contract labour from the New Hebrides essentially in order to “exploit its agricultural and mining resources" (Shineberg 3). New Caledonia and Australia, who celebrated their $70^{\text {th }}$ anniversary of bilateral relations in 2010 , therefore share a common history of colonisation based on the deportation of white convicts and coloured people, for political and economical reasons.

Australian South Sea Islanders' history and the conditions of their arrival on the continent have already been much debated by scholars from JCU, ANU or UQ like Clive Moore, Patricia Mercer, Doug Munro, Roger Keesing, or Kay Saunders to name a few, but their personal writings and their fight to retrace their family histories still need to be explored insofar as they provide a meaningful insight into the process of culture and identity making at work in that community from the 1970's onwards. The task is a complex one, if we take into account the facts that South Sea Islanders came from various geographical areas and settled in Australia under different circumstances.

Nowadays, Australian South Sea Islanders mainly live in North Queensland near the places formerly associated with the sugar industry like Mackay, Bowen, Rockhampton or Ingham, although some of the younger generations keep moving to Cairns or Townsville for better job opportunities. According to Clive Moore in his "Historiography of Immigrant Melanesians in Australia”, these people represent "the largest group of Melanesians living outside the islands" (77).They are descended from those who decided to stay despite the restrictions imposed by the 1901 Pacific Islands Labourers Act that put an end to the importation of Melanesian workers and planned their return to their home island. About 1,500 out of some 10,000 Islanders were thus allowed to stay and perhaps 1,000 managed to settle illegally (Delathière 17). For the second time in 50 years, family ties were broken and traditional knowledge was threatened, hence the title chosen by the writer Noel Fatnowna for his novel Fragments of a Lost Heritage.

Like Aboriginal people and Torres Strait Islanders, South Sea Islanders had to face racial discrimination, marginalisation, deprivation and humiliation in their everyday life, as explained in the biographical or autobiographical novels by Faith Bandler, Mabel Edmund and Noel Fatnowna. All three writers have a Melanesian ancestor from Vanuatu, Lifou or the Solomon Islands. Their personal accounts, published between 1977 and 1996, were so far the first ones to be written by members of that community in the post-deportation era. They therefore constitute valuable testimonies of Australian South Sea Islanders' history that has been orally transmitted from generation to generation since the arrival of their first ancestor. Their writings also emphasize a need to come to terms with their cultural heritage and distinct identity in a country which is now their own. As opposed to Faith Bandler and Mabel

\footnotetext{
${ }^{9}$ The word was also spelt Canaques in French from the end of the 19th century to the 1960's when it was considered as an insult.
} 
Edmund's intimist narratives told in the first or third person singular, Noel Fatnowna's novel clearly reveals the emergence of both a personal and collective identity, based on a community life which still existed 50 years ago and which is presented as an ideal model of cultural preservation, although it became seriously threatened by the adoption of a westernized way of living among young people especially. The recurring shift from "I" to "we" conveys the feeling of a strong cultural relationship between the individual and his community even if Fatnowna acknowledges that he was caught between two worlds with two different cultures (176). Welou, Bandler's young brother in her eponymous novel, experiences the same duality: "Welou or Warwick? The boy has two names, one from the Pacific Island of Ambrym, in what is now Vanuatu, where his father grew up, the other from his Australian baptism. Two names and two cultures: his mother and his warm-hearted Irish neighbours offer Warwick the sturdy traditions of Australia's white settlers, but campfire tales of village freedom and canefield bondage implant in Welou his father's Island values" (9). As for Mabel Edmund, she depicts herself as a "half-caste” or "an in-between" $(1,2)$ in No Regrets because of her Aboriginal and South Sea Islander ancestry. ${ }^{10}$

That duality caused deep divisions in the community itself but the emergence of three South Sea Islander writers and the publication of their works clearly contributed to the revival of their culture in the 1970's, when families tried to renew the link with their home islands. In the introduction of her first novel Wacvie, Faith Bandler explains that she wrote the book after her return from Ambrym Island in Vanuatu, where her father had been abducted. Her purpose was to tell his story and thus give a voice to all those who had been "enslaved". She also intended to reveal a part of Australia's history that had been erased from people's memory. Writing therefore became a symbol of political empowerment in which the "I" emerged as a subject in a postcolonial context, despite the occasional contributions/disruptions of white editors. $^{11}$

Besides, by the 1980's, Bandler, Edmund and Fatnowna had all got involved in political activism along with Aboriginal people for equal rights and social justice at large. In fact, Bandler's literary career started after she had stepped down as a General Secretary of the Federal Council for the Advancement of Aborigines and Torres Strait Islanders in 1973. Ten years later, she dedicated two books to her political involvement with Australia's Indigenous people to defend their rights. Similarly, in the 1970's, Mabel Edmund joined the Aboriginal and Torres Strait Islander Legal Service (ATSILS) and then in 1973, she was appointed as a Commissioner of the Aboriginal Loans Commission to help Aboriginal people buy a house (Edmund 72). Her political activities are related in the second part of her novel whereas the first one conjures up her family history. As for Noel Fatnowna's narrative, it is divided into 4 parts which respectively focus on his life and his trip back to the Solomons, then on his grandfather's and father's story but his involvement in the former Aboriginal and Torres Strait Islander Commission (ATSIC) as a Special Commissioner for Pacific Islanders is not mentioned.

\footnotetext{
${ }^{10}$ The Aboriginal poet and film-maker Romaine Moreton conjures up the same issue of social marginalisation for mixed race children in her poem entitled Sugar Slave:Sweet Life (59).

${ }^{11}$ We have to keep in mind that anthropologist Roger Keesing, who had done field work in the Solomon Islands among the Kwaio from Malaita, helped Fatnowna in the writing of his book and added notes when he considered that further explanations were needed. Similarly, Faith Bandler coedited two books with her long-time friend Len Fox, an Australian writer and painter.
} 
From the 1970's to the 1990's, South Sea Islanders became gradually more visible in the political landscape with the official recognition of their community as a distinct cultural group by the Commonwealth Government in 1994, then in September 2000 by the Queensland government who acknowledged their contribution to the economic development of that state through their toil. At about the same period, from 2000 to 2002, more recent narratives emerged in a new form combining summaries of people's lives written by themselves or others and personal documents such as photographs, family trees or genealogical data. These accounts were related in a factual, non-fictionalised style. We are here referring to Teresa Fatnowna's A Journey of Three Fatnownas, which relates the story of another branch of the Fatnowna family on three generations and to 3 among Many: a Collection of Life Stories from Mackay's Aboriginal, Torres Strait and Australian South Sea Islander Elders compiled by Justin Doyle, Grahame Fatnowna and Teleal Ketchell. Whereas the first book aims at keeping alive the memory of Teresa's husband and pays tribute to him, the second one provides photographs and short autobiographical accounts from the elder members of the three cultural groups aforementioned. In their foreword, both books emphasize the need to pass knowledge down to the next generations so that young people may know who they are and where they come from. Other publications from that period adopt a more historical perspective by compiling oral documents as in Fields of Sorrow: Oral History of the Mackay South Sea Islanders (Kanakas) and their Descendants or The Forgotten People. In On Plantation Creek: a Community History of the Australian South Sea Islanders in the Burdekin Shire, Lincoln Hayes retraces a community history in collaboration with its members.

All those written documents therefore come to complete the oral testimonies supplied by other media like recorded interviews or filmed documentaries on South Sea Islanders such as Sugar Slaves for instance, in which we are invited to follow Joe and Monica Leo ${ }^{12}$ through their trip back to Vanuatu on Pentecost Island where they found some of their relatives and identified the beach where their grand-father and father were taken. In For Who I Am, Bonita Mabo, the widow of the late Eddie Koiki Mabo, ${ }^{13}$ reveals her South Sea Islander ancestry and tells us about her fight for the recognition of her people after her husband's death because she considers that they are "a forgotten race" since "nobody knows about us". Moreover, while her husband was alive, she explains that she never spoke of her people to their children, as they were brought up as Torres Strait Islanders.

So what remains of South Sea Islander culture today, especially as there seems to be very few writers emerging from the younger generation and most stories written by South Sea Islanders are now out of print and their author deceased? The web may provide an interesting "alternative" perspective, as curator Jenny Fraser puts it in her online multi-art form exhibition programme called “The Other APT”, in which APT stands for "Alter-Native Perspectives Triumph". This exhibition was launched in December 2009 by Cybertribe, an online curating website which now features artworks by Krishna Nahow-Ryall, a South Sea Islander visual artist inspired by her family history and notably known for her 2009 Blakbird series of photographs. In 2010, she won the Commonwealth Connections International Art Residencies and chose to learn traditional "textile and women's adornment techniques" (Miller 68) at the Vanuatu Cultural Center on Mota Lava Island where some of her ancestors came from. Her

\footnotetext{
12 Two active members from the Rockhampton Australian South Sea Islander community.

${ }^{13}$ Mabo was a Torres Strait Islander from Murray Island who fought for his people's land ownership. He gave his name to the famous 1992 High Court decision on Native Title which overturned the concept of "terra nullius” in Australia.
} 
visual performances originally combine these techniques with modern media so as to convey a contemporary message prone to reconnect young South Sea Islanders with their Melanesian heritage.

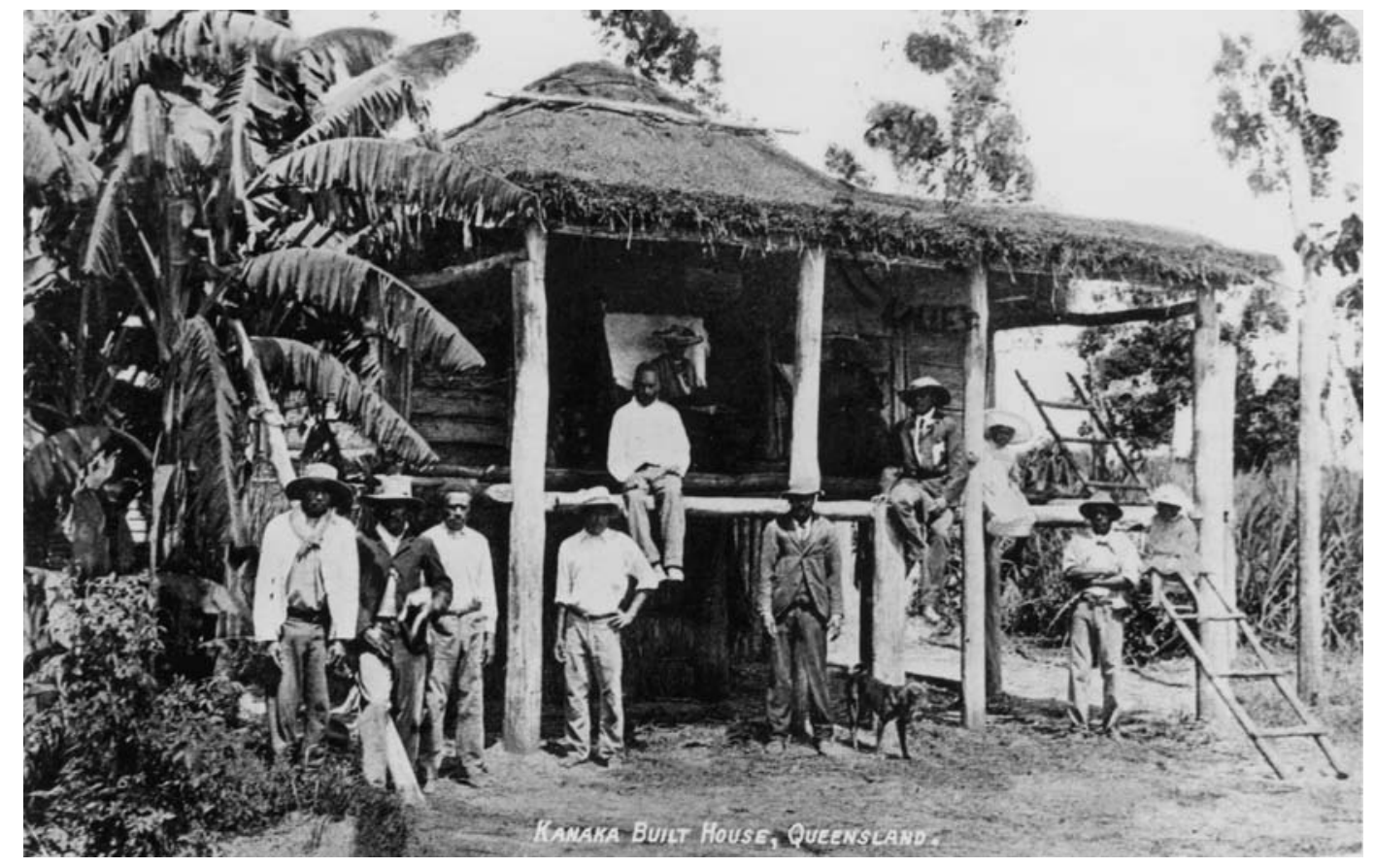

StateLibQld 1122274 South Sea Islanders standing in front of a house in Mackay in 1907.jpg. Retrieved from Wikimedia commons.

In New Caledonia, a first display on the Loyalty Islanders in Queensland was held at the Berheim Library in Nouméa. As a matter of fact in 2001, Robert Longhurst and Suzanne Grano organized a travelling exhibition entitled "Across the Coral Sea: Loyalty Islanders in Queensland" which was originally held at the Museum of Tropical Queensland in Townsville and ended at the Bernheim library in Nouméa. It gathered 32 photographs ${ }^{14}$ portraying Loyalty Islanders' life in the sugar cane plantations. When we recently came to visit three Lifou families who have relatives living in Queensland, they all remembered this display with some pride because for the first time, they had been given the opportunity to share their testimonies, photos and genealogical information on their ancestors' story and subsequent life in Australia. However, the latter were not abducted from their home and followed Samuel MacFarlane from the London Missionary Society to Darnley Island ${ }^{15}$ where they built temples before starting to work in the cane fields of Queensland. In fact they belonged to a second wave of Loyalty Islanders who willingly came to settle in Australia in the 1870's as opposed to a first wave of people who had arrived ten years earlier to work as indentured labour on the sugar cane plantations. In 2004, young members of the Ombres et Lumières Association in New Caledonia travelled to Queensland to meet the descendants of those Loyalty Islanders. They took photos which were displayed in 2006 at the Tjibaou Cultural Centre in Nouméa. Those two exhibitions opened a space for dialogue between people from different generations and places, be it from the mainland or the Loyalty Islands.

\footnotetext{
${ }^{14}$ These photographs were printed from the original ones at the John Oxley Library in Brisbane and they were eventually given to the Easo Museum in Lifou by the Australian Consulate.

15 Torres Strait Island also known as Erub.
} 
In conclusion, we can say that despite the ordeals they went through and their small number, Australian South Sea Islanders managed to settle in Australia and today, they keep on fighting for the preservation of their identity and the promotion of their culture and history. Their writings, films or displays as well as their use of the web to share videos and testimonies show their growing awareness of the need to understand who they are and where they come from to find their place in this country Further developments of the South Sea Islander culture are to be expected in the coming years across Australia, especially with the celebration of the $150^{\text {th }}$ anniversary of the first Islanders who came to work on the sugar cane plantations in 2013. On a larger scale it is hoped that our project will cast light on how migrant labourers' communities from Asia or the Pacific Islands for instance (Ball 9) manage to settle in Australia and make it their own country when they manage to get a visa.

\section{WORKS CITED}

Andrew, Cristine, and Penny Cook, eds. Fields of Sorrow: Oral History of the Mackay South Sea Islanders (Kanakas) and their Descendants. Mackay: Australian South Sea Islanders United Council, 2000. Print.

Ball, Rochelle. "Labour Mobility and Worker Vulnerabilities: The Case of Pacific Islanders in Australia.” Labour Mobility in the Pacific Project: State, Society and Governance in Melanesia Program. Australian National University, Canberra, ACT. 2009. Web. 19 November 2011.

Bandler, Faith. Wacvie. Australia: Rigby, 1977. Print. . Welou, My Brother. Australia: Wild and Woolley Pty. Limited and Aboriginal Artists Agency Limited, 1984. Print. Turning the Tide: A Personal History of the Federal Council for the Advancement of Aborigines and Torres Strait Islanders. Canberra: Aboriginal Studies Press, 1989. Print.

Bandler, Faith, and Len Fox, eds. The Time was Ripe: A History of the Aboriginal-Australian Fellowship. Chippendale: Alternative Publishing Cooperative, 1983. Print.

Bensa, Alban. Chroniques Kanak. L'ethnologie en marche. Paris: Ethnies-Documents, 18-19, 1995. Print.

Doyle, Justin, Grahame Fatnowna, and Teleal Ketchell, eds. 3 among Many: a Collection of Life Stories from Mackay's Aboriginal, Torres Strait and Australian South Sea Islander Elders. Mackay: Info Publishing Pty Ltd, 2000. Print.

Edmund, Mabel. No Regrets. Australia: University of Queensland Press, 1992. Print.

Delathière, Jerry. “Histoire des travailleurs insulaires du Pacifique: les Kanakas.” Société d’Études Historiques de la Nouvelle-Calédonie 162 (2010) : 1-24. Print. 
Fatnowna, Noel, and Roger E. Keesing, ed. Fragments of a Lost Heritage. Australia: Angus and Robertson Publishers, 1989. Print.

Fatnowna, Teresa, and Christine Fatnowna, ed. A Journey of Three Fatnownas (1866-1999). Mackay: Info Publishing Pty Ltd, 2002. Print.

For Who I Am: Bonita Mabo. Dir. Danielle Maclean. Prod. Hamlyn M. CAAMA Productions, 2002. DVD.

Hayes, Lincoln. On Plantation Creek: a Community History of the Australian South Sea Islanders in the Burdekin Shire. Ayr: Burdekin Shire Council, 2002. Print.

Krupat, Arnold. For Those Who Come After: A Study of Native American Autobiography. California: University of California Press, 1989. Print.

Le Clézio, Jean-Marie Gustave. Raga : Approche du continent invisible. Paris : éditions du Seuil, 2006. Print.

Miller, Imelda. “Krishna Nahow-Ryall: Blakbird.” Art Monthly Australia 232 (2010): 68-69. Web. 14 February 2011.

Minniecon-Smith, Sonia. Storian Blong Yumi Summer 2011. Web. $20^{\text {th }}$ January 2012.

Moore, Clive. "Revising the Revisionists: the Historiography of Immigrant Melanesians in Australia.” Journal of Pacific Studies 15. 2 (1992): 61-86. Print. . The Forgotten People: A History of the Australian South Sea Islander Community. Sydney: The Australian Broadcasting Commission, 2001. Print.

Moreton, Romaine. Post Me to the Prime Minister. Alice Springs: IAD Press, 2005. Print.

Shineberg, Dorothy. Ils étaient venus chercher du santal. Étude sur le trafic du bois de santal en Nouvelle-Calédonie et aux Nouvelles-Hébrides de 1830 à 1865. Trans. André Surleau. Nouméa : Société d’Etudes Historiques de la Nouvelle-Calédonie 3, 1973. Print. . The People Trade: Pacific Island Laborers and New Caledonia, 18651930. Honolulu: University of Hawai‘i Press, 1999. Print.

Sugar Slaves. Dir. Trevor Graham. Prod. Connolly S. Australian Broadcasting Distribution, 1995. DVD.

Wyberg, Docker, The Blackbirders: The Recruiting of South Sea Labour for Queensland. Sydney: Angus and Robertson, 1970. Print. 